\title{
ARTICLE
}

\section{Transforming The Institution from the Inside: Creating the Brave New Community College of the Future}

\author{
Jim Riggs, Professor, California State University, Stanislaus
}

\begin{abstract}
With rising and wide spread expectations that community colleges will become stronger forces throughout the nation, the stage is now set for these institutions to become even bigger players in the landscape of higher education, economic development and social justice by helping to create a more inclusive, well-educated and engaged citizenry. This article looks inward at what community college leaders, faculty and student services professionals need to do to transform their institutions into colleges that are truly ready to meet these rapidly growing expectations and to be able to take full advantage of these new opportunities. Four key areas at the institutional level are discussed that must be addressed in order for
\end{abstract}

community colleges to make substantial and necessary improvements in student learning and development. These include: (1) expanding the definition and understanding of what leads to student learning and success; (2) realigning and tightly coupling every function and activity at the college to better support student learning and success; (3) confronting the myth that community colleges are innovative and flexible institutions; and (4) instituting a new kind of leadership that is focused firmly on improving student learning and success. There are enormous opportunities waiting for community colleges that will require dramatic transformation and change throughout the organization.
Community colleges have long suffered from being perceived by many as last choice postsecondary institutions for recent high school graduates and returning adult students who could not get into or did not have the resources to go to a university. We often heard that community colleges were good places to attend for someone to get general education requirements "out of the way," take a recreational course, or "learn a skill in order to get a job." These were also places where one could learn English, prepare for the high school equivalency examination or take remedial mathematics and English courses. Rarely did we hear that community colleges were places where students could receive quality higher education. In short, community colleges have suffered from a public perception that they were somehow not quite "real" colleges.
Much of that perception has changed now. Over the past five years community colleges have evolved into the "darlings" of higher education and the nation. Numerous celebrities, along with the President of the United States, are singing praises of the community college. Community colleges have even captured the ongoing attention of the popular press. Finally, there is a long overdue and growing recognition of the value community colleges have to local and regional economies, and their legitimate place in the landscape of higher education. With the anticipation that by the year 2018 nearly two-thirds of all job openings will require some postsecondary education coupled with the fact that by 2025 America will need 20 million more college graduates to support the economy, the network of nearly 1200 community colleges across the country is expected to become an even stronger and more vital force 
in the economic and social health of the nation (Carnevale \& Rose, 2011).

This article looks inward at what community college leaders need to do to transform their institutions into colleges that are truly ready to meet these rapidly growing expectations. Four key areas at the institutional level are discussed that must be intentionally and aggressively addressed in order for community colleges to make substantial and necessary improvements in student learning and development. These include developing a much tighter coupling between educational programs and student services, implementing strategic and systemic changes in the organizational structure and operations, and building a much stronger and cohesive relationship between college leaders, the faculty and student services professionals. It will also require a much broader understanding and support for all of the elements beyond the formal teaching and learning process that directly influence and facilitate student learning and adult development. If community colleges want to take full advantage of the many new opportunities that the future holds, they will need to be redesigned from the inside out to create an institutional environment that fully supports and facilitates a kind of symbiotic and collective effort across the college that will lead to a dramatic increase in success for all students.

At the national level there have been pledges to substantially increase completion rates and to produce many more college graduates, while simultaneously making community colleges free and accessible to all those who can benefit (American Association of Community Colleges [AACC], 2015). At the state level, there have been recent calls for legislation and policies that focus on improving success rates by increasing funding for support services and creating more rigid and defined educational pathways for students (California Community Colleges Student Success Taskforce [CCC SSTF], 2012; Little Hoover Commission, 2013). In addition, with the belief that community colleges have the ability to provide superior technical education and because of their wide accessibility, an increased number of states now allow community colleges to offer specialized bachelor's degrees (California Community Colleges Chancellor's Office, 2014; Chen, 2015).

Despite all the attention and recent praise for community colleges, most educational leaders would agree that there still are numerous challenges that must be addressed. These include low graduation and completion rates, a continuing escalation in remediation needs, lack of currency in vocational programs, and a chronic scarcity of funding to meet current demands. These challenges are not new. What is new is the changing tide for community colleges from being underappreciated and not appropriately recognized for their major contributions, to being widely praised as the institutions that are going to help increase America's global competitiveness. National and state leaders from all political persuasions are also looking to community colleges to lead the efforts to addressthe growing problem of income inequality by providing educational opportunities for those historically left behind by traditional four-year colleges and universities.

The current and growing expectations for what community colleges can deliver may now be too optimistic. Community colleges continue to be under supported in relation to other higher education sectors. Even more disconcerting is that community colleges are organized and functioning much like they did 40 years ago with little change except for the integration of technology and an escalation in the use of adjunct faculty. Most community colleges of today are essentially the same organizations and operate much like they did in the 1970's. As a result, completion rates for degrees continue to be low, dropout rates continue to be high, and students are too often poorly served by these institutions.

The combination of low graduation rates and high dropout rates, as well as growing expectations for community colleges to help grow the economy, have not gone unnoticed by many educational leaders and scholars of community colleges. Beginning around 2010 a number of taskforce reports and white papers have been widely circulated which call for improving student learning and success by revitalizing, rebooting, reimagining, retooling and reinventing the community college (AACC, 2012; CCC SSTF, 2012; Community College League of California, 2010; Nodine, Venezia, \& Bracco, 2011; Pusser \& Levin, 2009; Research and Planning Group for California Community Colleges [RP Group], 2012, 2013). These reports have provided educational leaders with excellent recommendations and a strong push for fundamental changes in the community college enterprise. However, for community colleges, there has never been a shortage of calls for innovation, pledges to improve, proposed new frameworks, and outlines of numerous plans to guide future efforts. 
At the beginning of each decade for the past halfcentury we have heard similar calls for changes and improvements in the community college. Each decade took on a particular focus, but the calls were all similar in their push for fundamental change and innovation within the community college. The focus of the1960's and 1970's was on student access and improving general education. In the 1980's the emphasis shifted to improving the teaching process and increasing vocational education opportunities. During the 1990's, concerns moved toward global competitiveness and improving student learning. The first decade of the twenty-first century stressed accountability and providing "proof" of student success. There was a rise in scrutiny from accreditors and a great deal of rhetoric about student learning outcomes and institutional effectiveness.

However, by the end of each of these decades we could only look back to see in reality, little change and improvements had actually occurred. History has shown that these decennial calls for change and expectations for widespread innovation and improvements rarely manifested in long-term transformative actions at the community college. To jump start the calls for improvement in the current decade, leaders from six major national community college organizations came together in 2010 and signed a brief one page document entitled, Democracy's College: Call to Action and pledged to "produce 50 percent more students with high quality degrees and certificates by 2020, while increasing access and quality" (AACC, 2015, p. 23).

There is a growing recognition that if America is to remain economically competitive, there will need to be a substantial increase in the number of college degrees earned in the years to come (Carnevale \& Rose, 2011; Carnevale, Smith, \& Strohl, 2010; Public Policy Institute of California, 2015; Smith, 2010). This coupled with the fact that earning a college degree can serve as a great equalizer in addressing income inequality, the bar has been raised higher for community colleges than it has ever been. The stage is now set for community colleges to step up to the next level and become even bigger players in the landscape of higher education, economic development and social justice by helping to create a well-educated and engaged citizenry. Clearly, this is a tall order for institutions that are relatively resource poor, bureaucratically hamstrung and set in their ways of operating.
Even though these recent reports have provided some framework for change, they have fallen short in offering a clear, step-by-step way that colleges can improve their operations in order to have the capacity to implement many of the excellent ideas. There appears to be a fundamental but flawed assumption on the part of the authors of these reports that most community colleges, as they are currently designed and function, can simply and easily implement whole scale innovations and institution-wide improvements. The reality is that community colleges, like all other sectors of education, are amazingly resilient when it comes to resisting and avoiding change and impervious to outside pressures to make the fundamental changes necessary to improve student learning and success (Elmore, 2004; George, Chattopadhyay, Sitkin \& Barden, 2006; Jenkins, 2011; Ravitch, 2004; Schmoker, 2006; Stein, 2004).

Despite the end of the "Great Recession" and the slow restoration of funding, resources will still be inadequate to add large-scale new programs that could improve student learning and success. Any new monies that come to the colleges will most likely be allocated to long overdue salary increases as well as for restoring funding for critical operations of the college. If improvements are to occur at the community college, they will need to come from within the organization and funded by the colleges themselves. Right now community colleges have a golden opportunity to make systemic changes rather than following the usual path of adding and layering on new programs and services that may only serve a small portion of the student population.

The national spotlight can be a double-edged sword for community colleges. On the one hand this newfound attention can provide a greatly needed nudge toward making long overdue transformative changes and systemic improvements. On the other hand, if community colleges fail to make the changes necessary to dramatically improve student learning and success, they will certainly fall short when it comes to meeting the rising expectations that have been thrust upon them. Will community colleges rise up and make the necessary improvements to move to the next level of excellence? Not likely unless there is a sea change in how the colleges are organized, operate and led. Community colleges will also need to come to grips with the fact that they simply cannot be everything to everyone and must be more realistic about 
what they are capable of delivering. If community colleges continue with business as usual, it is quite possible that at the start of the next decade, we will once again see a flurry of taskforce reports and emotion filled pledges to improve student learning and success.

Unfortunately, community colleges have become trapped in a kind of iron cage of their own making, where they continue to operate with the unspoken but well understood agenda of perpetuating the status quo, while at the same time giving the illusion that they are flexible and innovative institutions. Clearly, as many of the taskforce reports and white papers point out, the status quo simply will not work if these institutions are going to serve as a major pathway toward economic self-sufficiency for the majority of Americans and a vital democratizing force in our country. What these reports have failed to do is to give community colleges any guidance on how to escape from their iron cage.

\section{Breaking Out of the Iron Cage}

The metaphor of the iron cage is used to describe the trap that institutions can put themselves into by continuing to follow outdated organizational routines and maintaining dysfunctional, self-serving institutional structures (Ashworth, Boyne \& Delbridge, 2007; DiMaggio \& Powell, 1983). The community colleges' iron cage consists of uncontested and self-limiting beliefs about what actually facilitates learning and leads to student success. At first blush, one may think that community colleges would confront and escape the self-limiting confines of their iron cage, but on closer examination, there is a kind of comfort zone inside of acceptable and "taken for granted" routines and unquestioned beliefs about how the colleges should operate. Moreover, there is a sense of vulnerability and a fear of what may lie outside the cage. This cage also serves as a force field to protect and buffer these institutions from external pressures.

For the purpose of this discussion, the iron cage has been broken down into four broad areas, each representing a part of the cage that serves to keep community colleges from taking the steps necessary to transform into dynamic student centered institutions. If community colleges are truly going to undergo the transformative changes necessary to dramatically improve student learning and success they will need to address the following critical areas by: (1) expanding the definition and under- standing of what leads to student learning and success; (2) realigning and tightly coupling every function and activity at the college to better support student learning and success; (3) confronting the myth that community colleges are innovative and flexible institutions; and (4) instituting a new kind of leadership that is focused firmly on improving student learning and success. This will take hard, sustained work on the part of every employee and a willingness to change. It will also take a unified core of leaders who are willing to take risks and are committed to dramatically transforming their organizations into highly efficient and effective educational organizations. The starting point will be to identify all learning opportunities throughout the college that, if they were designed and facilitated appropriately, could provide for well-coordinated educational experiences for students. This will require expanding the technical core of the college to include those aspects beyond the classroom that contribute to knowledge acquisition and development.

\section{Expanding the Technical Core of Student Learning and Success}

The technical core of an educational institution can be defined as those elements within the organization that directly influence and lead to student learning and success (Coburn, 2004; Spillane, Parise \& Scherer, 2011; Weick, 1976). Unfortunately, the technical core is often viewed only narrowly as the formal teaching/learning process within the classroom and is confined to pedagogical functions. However, there is a growing understanding of the value of engaging students in many different ways throughout their experience at the college and how these actions support transformative learning and student development (Cranton, 2006; Gardiner, 1994; Kuh, Douglas, Lund \& Ramin-Gyurnek, 1994; Weinbaum, Rodriguez, \& Bauer-Maglin, 2013).

The first step that community colleges must take is to create a comprehensive framework that includes all inputs, structures, functions, and environmental issues within the college that directly influence student learning and success (NASPA/ACPA, 2004; RP Group, 2012, 2013). In other words, there needs to be a broader and more holistic understanding of what the Technical Core of Student Learning and Success (Technical Core) consists of at the community college. Table 1 below identifies components that would be included in an expanded model of the 
Table 1

Technical Core of the Community College

\begin{tabular}{|c|c|}
\hline $\begin{array}{l}\text { Component of the } \\
\text { Technical Core }\end{array}$ & Description \\
\hline Pedagogy & The traditional teaching/learning process \\
\hline $\begin{array}{l}\text { Course and Program Content } \\
\text { and Sequencing }\end{array}$ & $\begin{array}{l}\text { Content and learning strategies employed; how the content and learning strategies } \\
\text { are sequenced, articulated and scaffolded within individual courses and through a } \\
\text { program of study }\end{array}$ \\
\hline $\begin{array}{l}\text { Course and Program } \\
\text { Availability and Modality }\end{array}$ & $\begin{array}{l}\text { How courses and other learning opportunities are sequenced throughout the } \\
\text { program including the level of predictability that necessary courses are available and } \\
\text { accessible to the students, and modality(ies) used to deliver the courses and program }\end{array}$ \\
\hline Learning Environments & The physical and intellectual environments where learning occurs \\
\hline Learning Support & $\begin{array}{l}\text { The support programs and services in place to assist students with learning; } \\
\text { programs are generally outside the classroom, oftentimes voluntary, and can be } \\
\text { general learning support or specific to a course or a discipline }\end{array}$ \\
\hline $\begin{array}{l}\text { Student Support and } \\
\text { Development }\end{array}$ & $\begin{array}{l}\text { Programs and services that provide assistance with educational program planning, } \\
\text { career exploration, time management, problem solving, values and priorities } \\
\text { clarification and emotional support }\end{array}$ \\
\hline $\begin{array}{l}\text { Faculty/Key Staff } \\
\text { Characteristics, Skills and } \\
\text { Disposition }\end{array}$ & $\begin{array}{l}\text { Capability of faculty and other key staff to facilitate student learning and } \\
\text { development; including important attitudes and a positive mindset of the faculty and } \\
\text { key staff toward student learning and success }\end{array}$ \\
\hline $\begin{array}{l}\text { Student Characteristics, Skills } \\
\text { and Disposition }\end{array}$ & $\begin{array}{l}\text { Students' capacity for learning at the appropriate level; their ability to navigate the } \\
\text { college environment in order to take advantage of support programs, complete } \\
\text { routine administrative functions including registration and applying for financial } \\
\text { aid; student attitudes about their ability to learn, level of responsibility for their own } \\
\text { learning, and for being resourceful; students' mindset about the value of going to } \\
\text { college as well as how they view the programs, services, faculty and other key staff }\end{array}$ \\
\hline
\end{tabular}

\section{Technical Core.}

The proposed Technical Core has been expanded in three ways from the more traditional view of the technical core. First, the new model recognizes many other critical aspects in addition to the teaching/learning process that may influence student learning and success. Second, it recognizes that student learning is influenced by the context and environment within which the learning process takes place. Third, this model recognizes that student learning and success cannot be understood separately from the characteristics, skills and dispositions of the students, and those who do the teaching and provide student development services.

If community college students are to grow and mature into lifelong learners, they must be repeatedly exposed to well-coordinated educational experiences that focus on moving them through three levels of learning and knowledge development. Many of these educational opportunities occur outside the traditional classroom setting. The first level of learning includes acquiring technical knowledge that allows learners to develop a foundation of content and procedural learning that helps them to manipulate and control their environment. The second level focuses on acquiring social knowledge and how to develop meaning out of learning experiences. The third level concentrates on developing knowledge that leads to personal growth and empowerment, where students learn to be self-directed, reflective, and responsible for their own future as well as others around them. Hallmarks include a strong self-efficacy, intellectual prowess, and resiliency (Cranton, 2006; Mezirow, 2000).

The expanded Technical Core also recognizes that many individuals between the ages 18 and 30 have not yet developed into full adulthood and are in a stage of development that is characterized by: (1) identity exploration, (2) instability, (3) self-focused, (4) feelings of being 
in-between adolescence and adulthood, and (5) an exposure to the many possibilities that lie ahead (Arendt, 2005; Côté, 1999). There is a growing recognition that student characteristics and behaviors can have a strong influence on success at the community college (West, Shulock \& Moore, 2012). Therefore, it is important that faculty and student services professionals intentionally provide educational experiences that can help shape positive dispositions toward education and behaviors that lead to a strong sense of efficacy and personal responsibility on the part of students. This kind of learning can occur outside the classroom and in informal settings around the college.

Each community college will need to assess all the components of its Technical Core to determine how, and to what extent, they are directly advancing student learning and development. Plans should be implemented to strengthen each of the Technical Core components first individually, and then to strengthen the overall Technical Core by better integrating and more tightly coupling each of the components with each other to create an integrated core that makes sense from the students' perspective. By expanding the Technical Core, the college can create a holistic environment that truly leads to transformative learning, where all of its components are expanded and integrated to better facilitate both the learning needs and the social/emotional development of students as they move fully into adulthood and begin to identify their place in the world.

\section{Redesigning the Community College Organization}

For seven out of the past eight years, community colleges have been faced with the largest financial crisis that they have ever experienced. There was an unprecedented and continuous drop in traditional resources at a time when most colleges had already been cut to the barebones. However, what started in 2007 was more than just another major economic downturn caused by a boom and bust economic cycle - it was, and continues to be, an outgrowth of permanent economic, political, societal and cultural shifts that have been occurring through out the United States.

College leaders must start using the shift in financial support and demographics as a window of opportunity to transform their institutions, and to challenge the traditional ways in which their colleges operate and are organized. This includes confronting and eliminating unnecessary barriers, and building more flexible organizations that can respond to the growing and changing learning needs of students (Jenkins, 2011). Leaders must also recognize that the traditional community college organizational structure, with separate and distinct divisions for instructional services, student services, and administrative services that operate primarily in isolation from each other, is an outdated artifact of the past and does not serve the best interest of students.

The traditional organizational structure often gets in the way of meaningful student engagement and learning by creating an artificial separation between what happens inside and outside the classroom (Kuh, Lund \& Ramin-Gyurnek, 1994). To truly engage and retain students, organizational barriers must be removed and there must be greater integration between student services, learning support programs and administrative support services, and what happens in the classroom.

Accrediting bodies throughout the nation are taking a closer look at how colleges are organized and function, and are requiring colleges to organize key processes and allocate resources more effectively to support student learning. Accreditation agencies are not only holding community colleges accountable for offering appropriate programs and services, but also for ensuring that these institutions have organizational structures which best support programs and services to achieve the goal of student learning (Accrediting Commission for Community and Junior Colleges, 2012). This will require all community colleges to identify ways to improve and change their organizational structures and processes; all within an environment of increasing accountability, limited resources, economic changes and demographic shifts.

It is essential that all community college leaders have the courage and skills to effectively confront the barriers and obstacles to student learning that are caused by outdated organizational structures and operations. They must transform their institutions into effective educational organizations that provide a well articulated learning environment - a place where learning and student engagement can take place anytime, both inside and outside the classroom. The first step for every community college is to develop a reorganization plan that integrates and consolidates instruction, learning support, and student support programs into a coherent network that can be easily accessed and navigated by students. 
Colleges must ensure that all the support functions and structures of the community college operation that lie outside the Technical Core are reviewed, and then repositioned and redesigned to provide the best support possible for those areas that directly facilitate student learning and success. These must first be broken down into individual components, key functions, structures and systems, and then reconstructed in such a way that every effort and action throughout the organization, whether directly or indirectly, supports student learning and success.

Complicating efforts to change the operating culture and organizational logic of the college is the common use of language such as "other side of the house," "my students," "student services perspective" and "administration." Such debilitating and restrictive language serves as a way to preserve the status quo by maintaining an us versus them mentality and emphasize separate roles for the various departments and services within the community college organization. Those responsible for leading change in their institution must pay particular attention to how all of the employees and students, as well as key external stakeholders make sense out of the organizational and operational changes (Fiss \& Zajac, 2006; Weick \& Sutcliffe, 2005). College leaders will need to construct a new and shared understanding or "sensemaking" about how the changes in the organization will improve student learning and success (Eddy, 2010). Developing and implementing a new set of descriptors and a consistent language palette that support the changes will go a long way in reshaping the way employees and stakeholders make sense out of the new way of operating, and will lead to a new kind of organizational logic (Greenwood, Diaz, Li \& Lorente, 2010). Once a new understanding of the organizational changes is established and expressed collectively as the "way we do business around here," behaviors will begin to reinforce and support the new organizational structure, and the tighter integration among all programs and services.

\section{Confronting the Myth of Innovation}

Community colleges have always been ahead of other higher education sectors in developing and implementing curriculum and instructional innovations and "best practices," (League of Innovation in the Community College, 2010). Unfortunately, this has promoted the mistaken belief that community colleges, by nature and de- sign, are innovative and flexible. The reality is that most of the "best practices" at the community college are implemented in isolated parts of the institution and rarely, if ever, adopted at a level where the majority of students can benefit (Jenkins, 2011). These are mostly small "boutique" innovations that are fueled by short-term grants, and fizzle away once the external money is gone. Colleges almost always fail to incorporate these innovations into the sustainable core fabric of their operations.

The myth that community colleges are innovative and flexible institutions has helped to shape a false sense of identity of who these institutions really are and what they are actually capable of accomplishing. The myth is perpetuated in many ways including news articles in the popular press that focus on novel programs as well as continuous presentations to governing boards and civic groups that showcase "best practices" in isolation from the large body of educational programs and wide array of support services. In addition, much of the marketing and fundraising materials that are developed feature innovative programs, again in isolation from the bigger picture of the college as a whole.

By over emphasizing novel innovations and presenting them in such a way that they are viewed as a general representative of the college has led to the widely held belief (both inside the college and in the minds of the general public) that community colleges are more dynamic and "cutting edge" than they really are. This in turn has led to a kind of false sense of confidence, where there is the assumption that community colleges are highly efficient and innovative educational institutions. There is oftentimes a lack of scrutiny and critical oversight of what is really happening in the other $90 \%$ of the programs and services at the college that never get showcased because they do not fall under the label of being innovative, unique or "best practices."

In reality, community colleges do not have the kind of entrepreneurial culture and degrees of freedom for experimentation that they may have had 50 years ago. In looking at where community colleges fall within an organizational lifecycle conceptual framework, most of these institutions have reached their cranky later middle-aged years where they are comfortable and very resistant to change (Quinn \& Cameron, 1983). The current community college environment is shaped by many things including the age and history of the institution, longevity 
of the faculty and staff, a resource dependent mentality, a rigid division of roles and responsibilities throughout the organization, a hodgepodge of external regulations and accountability requirements, and a product (course offerings and programs) that is standardized in many ways. All of these things work against risk-taking and innovation.

Although rarely acknowledged, community colleges, like other education institutions attract and are populated by individuals who are risk aversion by nature, and not entrepreneurs (Elmore, 2004; Schmoker, 2006). Educational institutions usually offer a great deal of job security in the form of tenure for faculty, permanent employment status for support staff, and multi-year contracts for administrators. With this kind of job security, it seems like employees would be encouraged and willing to take risks and be more innovative, but it appears this may have the opposite effect. Community colleges must come to terms with the reality that they have limitations and confront the destructive myth that by nature and design, they are agile, innovative and flexible institutions. It is essential that every college identify what can and cannot be reasonably accomplished on an institutional-wide basis.

\section{Moving Toward a New Kind of Leadership}

The failure to implement institutional-wide innovations in education can, in part, be attributed to the decoupling and disconnecting of the elements of the Technical Core from the concerns of the administration (Bidwell, 2001; Elmore, 2004). Clearly, administrators have challenging responsibilities and are constantly being pulled in multiple directions (Boleman \& Gallos, 2011). Unfortunately, too many campus leaders get so burdened by the day-to-day responsibilities of their programs and departments that they get lost in what could be called the white noise of educational administration.

This noise is a result of constant and wearisome administrative challenges and demands that are ever present at all levels of the college, and has a way of beating down those who want to reform their institution. It also causes leaders to lose sight of the fact that their college has only one goal - student success. Administrators begin to confuse balancing budgets, dealing with external constituents, implementing arduous regulations, resolving difficult personnel problems and the like, as goals of the institution. In reality, these and all other management functions, while critical to the success of the college, are means toward the goal of student success, and not goals unto themselves.

Community college leaders must place a greater emphasis on improving all functions of the college if they truly want to provide better support to the Technical Core. This includes assessing and making appropriate adjustments in the college's strategic planning processes, organizational structures and systems, stakeholder accountability practices, human resource processes, governance procedures, resource generation and allocation practices, material resource allocations, and college's compliance with regulations and accreditation requirements to make sure that each of these are, in some way, supporting the Technical Core of the institution.

Unfortunately, the ever-present white noise of educational leadership serves as one of the primary ways of protecting the status quo at our colleges. It is very distracting and often causes administrators to focus only on survival and self-preservation rather than providing the transformational leadership necessary to strengthen their institution. Support programs and operations that have been in place for years are difficult to change, and when change does occur, there can be a disturbing ripple affect across the institution which creates a deafening crescendo in the white noise to the point where many educational reformers simple give up. However, giving up and focusing only on survival are not options for college leaders if their institutions are to remain viable into the future.

Community college leadership is complex, unpredictable and at times messy. However, good leadership can be learned. Therefore, colleges must turn their focus toward better ways of retaining, developing and nurturing the leadership talent pool that already exists on their campuses (Mitchell \& Eddy, 2008). This talent pool is largely made up of entry level and mid-level administrators, who unfortunately are neglected when it comes to providing leadership growth opportunities (Dalpes, Baston \& Sanchez, 2015; Riggs, 2009). Many community colleges provide little or no ongoing and meaningful professional development opportunities for this group of leaders, while at the same time placing increasingly higher demands on them. Clearly, the environment that now exists at most community colleges is that of high demand and low support for its administrators.

Community colleges must institute a new kind of leadership that is focused firmly on improving student 
learning and success. This will require a major shift from the commonplace administrative practices of non-involvement and non-interference in the core teaching/ learning processes and student development functions to one that requires all leaders throughout the college to contribute in some way to the core functions that lead to student success.

\section{Brave New Community Colleges of the Future}

For the past 40 years, community colleges have too often looked to small solutions to address large problems, muddled through difficult times and have used short-term strategies that only got them through one calamity to the next. The desire for stability has continually trumped and squelched the kind of systemic innovations and transformational change that could lead to dramatic increases in student learning and success. With limited resources and facing a rapidly changing future, community colleges have reached a tipping point; a place where they will no longer be able to maintain all of their historical functions, conventional ways of operating, or garner enough support for all their traditional missions. The way community colleges have operated in the past, and for the most part function today, simply will not work if they want to escape from their iron cages and become the brave new community colleges of the future. This will require a whole new organizational logic where all efforts and resources are tightly integrated and focused on the single goal of improving student learning and success.

Community colleges are complex organizations with smart and engaged employees. The bottom line is that we know, as educational leaders, faculty, student services professionals and planners, which reforms work and which ones do not work when it comes to improving student learning and development. However, a smattering of department and program level innovations in isolated parts of the college will do little to facilitate transformative learning on a college-wide basis or improve completion rates. What is needed is a cohesive institutional environment that facilitates and supports a kind of symbiotic and collective effort across the college that will lead to a dramatic increase in success for all students. This will require a shared understanding of how and why systemic changes must occur and how student learning and development can be dramatically improved. It will also require all employees to embrace a future of uncertainty; with its myriad of challenges, wild cards, hidden opportunities and obstacles, and non-logical force fields of resistance. A future where there is a collective understanding and mutual responsibility on the part of everyone for the real consequences of action and inaction. There are enormous opportunities awaiting community colleges that will require new delivery systems, more effective organizational structures and fresh leadership approaches.

\section{About the Author}

Jim Riggs is the Professor of Community College Education at California State University, Stanislaus and teaches in the University's Doctorate in Educational Leadership Program. Before joining CSU Stanislaus in 2008, he served for over 30 years in several administrative and teaching positions at the community college level, including as the President of Columbia College in California from 1997 to 2007.

Email:jriggs1@csustan.edu 


\section{REFERENCES}

Accrediting Commission for Community and Junior Colleges. (2012). Accreditation Standards. Retrieved from www.accjc. org

American Association of Community Colleges. (2012). Reclaiming the American dreams: Community colleges and the nation's future. Retrieved from http://www.aacc.nche.edu/ AboutCC/21stcenturyreport/index.html

American Association of Community Colleges. (2015). Community college completion: Progress toward goal of $50 \%$ increase. Retrieved from http://www.aacc.nche.edu/AboutCC/ Trends/Documents/completion_report_05212015.pdf

Arnett, J. (2005). Emerging adulthood: Understanding the new way of coming of age. In J. Arnett \& J. Tanner, (Eds.), Emerging adulthood: Coming of age in the 21st century (pp. 3-19). Washington, DC: American Psychological Association.

Ashworth, R., Boyne, G. \& Delbridge, R. (2007). Escape from the iron cage? Organizational change and isomorphic pressures in the public sector. Journal of Public Administration Research and Theory, 19, 167-187.

Bidwell, C. (2001). Analyzing schools as organizations: Long-term permanence and short-term change. Sociology of Education, Extra Issue 2001, 100-114.

Bolman, L. \& Gallos, J. (2011). Reframing academic leadership. San Francisco, CA: Jossey Bass.

California Community Colleges Chancellor's Office. (2014). Report from California Community Colleges Baccalaureate Degree Study Group. Retrieved from: http://californiacommunitycolleges.cccco.edu/portals/0/reportsTB/2014_01_ BacDegree_StudyGroup_WEB.pdf

California Community Colleges Student Success Taskforce. (2012). Advancing student success in the California Community Colleges: Recommendations of the California Community College Student Success Taskforce. Retrieved from http://californiacommunitycolleges.cccco.edu/PolicyinAction/StudentSuccessTaskForce.aspx

Carnevale, A. \& Rose, S. (2011). The undereducated American. Washington DC: Georgetown University Center on Education and the Workforce.

Carnevale, A., Smith, N., \& Strohl, J. (2010). Help wanted: Projections of jobs and education requirements through 2018. Washington, DC: Georgetown University Center on Education and the Workforce.

Chen, G. (March 2015). Obtaining your bachelors degree at a community college. Retrieved from http://www.communitycollegereview.com/blog/obtaining-your-bachelors-degree-ata-community-college

Coburn, C. (2004). Beyond decoupling: Rethinking the relationship between the institutional environment and the classroom. Sociology of Education, 77(3), 211-244.

Community College League of California. (2011). 2020 Vision: $A$ Report of the 21st Century Commission on the Future of Community Colleges. Retrieved from http://www.cccvision2020. org/Portals/O/Documents/COTFReport.pdf

Côté, J. (2000). Arrested adulthood: The changing nature of maturity and identity. New York, NY: University Press.

Cranton, P. (2006). Understanding and promoting transformative learning (2nd ed.). San Francisco, CA: Jossey Bass.
Dalpes, P., Baston, M. \& Sanchez, F. (2015). Community college student affairs professionals at entry and mid-level. In A. Tull, L. Kuk \& P. Dalpes (Eds.), Handbook for student affairs in community colleges (pp. 381-297). Sterling, VA: Stylus.

DiMaggio, P. \& Powell, W. (1983). The iron cage revisited: Institutional isomorphism and collective rationality in organizational fields. American Sociological Review, 48(2), 147-160.

Eddy, P. (2010). Community college leadership: A multidimensional model for leading change. Sterling, VA: Stylus.

Elmore, R. (2004). Building a new structure for school leadership. In School reform from the inside out: Policy, practice, and performance. Cambridge, MA: Harvard Education Press.

Fiss, P. \& Zajac, E. (2006). The symbolic management of strategic change: Sensegiving via framing and decoupling. Academy of Management Journal, 49(6), 1173-1193.

Gardiner, L. (1994). Redesigning higher education: Producing dramatic gains in student learning. ASHE-ERIC Higher Education Report No. 7. Washington D.C.: The George Washington University.

George, E., Chattopadhyay, P., Sitkin, S. \& Barden, J. (2006). Cognitive underpinnings of institutional persistence and change: A framing perspective. The Academy of Management Review, 31(2), 347-365.

Greenwood, R., Diaz, A., Li, S. \& Lorente, J. (2010). The multiplicity of institutional logics and the heterogeneity of organizational responses. Organization Science, 21(2), 521-539.

Jenkins, D. (2011). Redesigning community colleges for completion: Lessons from research on high-performance organizations (CCRC Working Paper No. 24). New York: Community College Research Center, Columbia University.

Kuh, G., Douglas, K., Lund, J. \& Ramin-Gyurnek, J. (1994). Student learning outside the classroom: Transcending artificial boundaries (ASHE-ERIC Higher Education Report No. 8). Washington, DC: The George Washington University.

League of Innovation in the Community College. (2010). The nature of innovation in the community college. Phoenix, AZ: League of Innovation in the Community College.

Little Hoover Commission (2013). A new plan for a new economy. Retrieved from www.lhc.ca.gov

Mitchell, R. \& Eddy, P. (2008). In the middle: Career pathways for mid-level community college leadership. Community College Journal of Research and Practice, 32, 793-811.

NASPA/ACPA (2004). Learning reconsidered: A campus-wide focus on the student experience. Retrieved from http://www.myacpa.org/pub/documents/LearningReconsidered.pdf

Nodine, T. Venezia, A. \& Bracco, K. (2011). Changing course: A guide to increasing student completion in community colleges. San Francisco, CA: WestEd. Retrieved from http:// knowledgecenter.completionbydesign.org/sites/default/ files/changing_course_V1_fb_10032011.pdf

Quinn, R. \& Cameron, K. (1983). Organizational lifecycle and shifting criteria of effectiveness: Some preliminary evidence. Management Science, 29(1), 33-51.

Public Policy Institute of California (2015). California's future. Retrieved from: www.ppic.org.

Pusser, B. \& Levin, J., (2009). Re-imagining community colleges in the 21st century. Retrieved from http://www.americanprogress.org/wp-content/uploads/issues/2009/12/pdf/ community_colleges_reimagined.pdf 
Ravitch, D. (2004). Recycling reforms: The U.S. Department of Education has created an office in charge of funding innovation. Education Next, Winter 2004, 35-40.

Research and Planning Group for California Community Colleges. (2012). Understanding the student experience through the loss/momentum framework: Clearing the path to completion. Retrieved from http://www.rpgroup.org/sites/default/files/ CbD-Understanding.pdf

Research and Planning Group for California Community Colleges. (2013). Student support (Re)defined: Using student voices to redefine support. Retrieved from http://www.rpgroup. org/sites/default/files/StudentPerspectivesResearchReportJan2013.pdf

Riggs, J. (2009). Leadership for tomorrow's community colleges: Challenges and opportunities. The Community College Enterprise Journal, 15(2), 1-12.

Schmoker, M. (2006). Results Now: How we can achieve unprecedented improvements in teaching and learning. Alexandria, VA: ASCD.

Smith, P. 2010. Harnessing America's wasted talent: A new ecology of learning. San Francisco, CA: Jossey-Bass.

Spillane, J., Parise, L., \& Sherer, J. (2011). Organizational routines as coupling mechanisms: Policy, school administration, and the technical core. American Educational Research Journal, 48, 586-619.

Stein, S. (2004). The culture of education policy. New York, NY: Teachers College Press.

Weick, K. (1976). Educational organizations as loosely coupled systems. Administrative Science Quarterly, 22(1), 1-19.

Weick, K. \& Sutcliffe, K. (2005). Organizing and the process of sensemaking. Organization Science, 16(4), 409-421.

Weinbaum, A. Rodriguez, C. \& Bauer-Maglin, N. (2013). Rethinking the community college for the 21st century. New York City, NY: CUNY.

West, C., Shulock, N. \& Moore, C. (2012). Measuring institutional conditions that support student success in the California Community Colleges. Los Angeles, CA: UC/ACCORD. 
